\title{
Food selection and consumption of mobile epibenthic fauna in shallow marine areas
}

\author{
Leif Pihl \\ Institute of Marine Research, S-45300 Lysekil, Sweden
}

\begin{abstract}
Food selection and consumption of the dominant species among mobile epibenthic fauna was investigated in shallow waters on the Swedish west coast. Newly recruited Pomatoschistus microps, P. minutus, Pleuronectes platessa and Crangon crangon fed initially on meiofauna, whereas young stages of Carcinus maenas preferred 'detritus' (including plant material) and juvenile specimens of macrofauna. Older stages of all 5 species fed on macrofauna. In 1 yr (1977), when low recruitment of some usually abundant macrofaunal species occurred (Möller \& Rosenberg 1982, 1983), early postlarval stages of $C$. crangon were eaten mainly by $C$. maenas and $C$. crangon. The mobile epibenthic predators are considered opportunistic carnivores mainly feeding on infauna which they select on the basis of relative availability. Total annual food consumption of mobile epibenthic fauna in one area, Gullmarsvik 1978, was calculated to be $26 \mathrm{~g} \mathrm{AFDW} \mathrm{m}^{-2}$. Food conversion (P/C) was estimated to be about 0.2 for crustaceans and 0.3 for fishes. The mobile epibenthic fauna consumed 60 to $98 \%$ of the production of the dominant infauna: harpacticoid, ostracods, Corophium volutator, Mya arenaria and Cardium edule, and is considered as the major biotic regulator of the infauna. In general, food-niche overlap decreased with increasing difference in size between 2 predator species. C. volutator was preferred by all epibenthic predators during most seasons and in Gullmarsvik 1978 contributed on average about $60 \%$ of the food overlap between pairs of predators. $M$. arenaria and $C$. edule together made up about $70 \%$ of the food overlap in July and August in this year, and the mobile epibenthic fauna consumed 98,62 and $92 \%$ of the production of $C$. volutator, $M$. arenaria and $C$. edule, respectively. This strongly suggests that competition between predators exists for these infaunal species, at least during parts of the season.
\end{abstract}

\section{INTRODUCTION}

In shallow $(<1 \mathrm{~m})$ areas on the Swedish west coast the mobile epibenthic fauna mainly includes 5 species: Crangon crangon (L.), Carcinus maenas (L.), Pomatoschistus microps (Krøyer), P. minutus (Pallas) and Pleuronectes platessa (L.). These species are all common in the Dutch Wadden Sea and are considered there as the main carnivores in shallow soft bottom communities (Kuipers et al. 1981).

On the Swedish west coast Crangon crangon has the highest abundance, biomass and production among the epibenthic fauna (Pihl \& Rosenberg 1982); the food selection and consumption of this species was investigated in some areas by Pihl \& Rosenberg (1984). In one of the areas, predation of larger visiting fish also was investigated (Pihl 1982).

In this study food selection and consumption of the 4 other species of mobile epibenthic fauna on the Swedish west coast are investigated. Their consumption together with that of Crangon crangon is compared with the production of the infauna studied in the same project (Möller \& Rosenberg 1982, 1983). Food-niche overlap between these epibenthic species is also discussed. For simplicity, the terms 'mobile epifauna' or just 'epifauna' will be used instead of mobile epibenthic fauna in the following text.

\section{AREAS INVESTIGATED}

The investigation was carried out in 2 shallow (0 to $0.7 \mathrm{~m}$ ) water areas, Gullmarsvik and Sandvik, on the Swedish west coast during 1977 and 1978 (Fig. 1).

Seasonal variations in temperature (weekly means) were similar at the localities; they varied between 4 and $14^{\circ} \mathrm{C}$ in spring and autumn, and between 14 and $20^{\circ} \mathrm{C}$ in summer. The areas were usually covered by ice during winter (Dec-Mar). Salinity, based on daily means recorded each hour, fluctuated between 14 and 


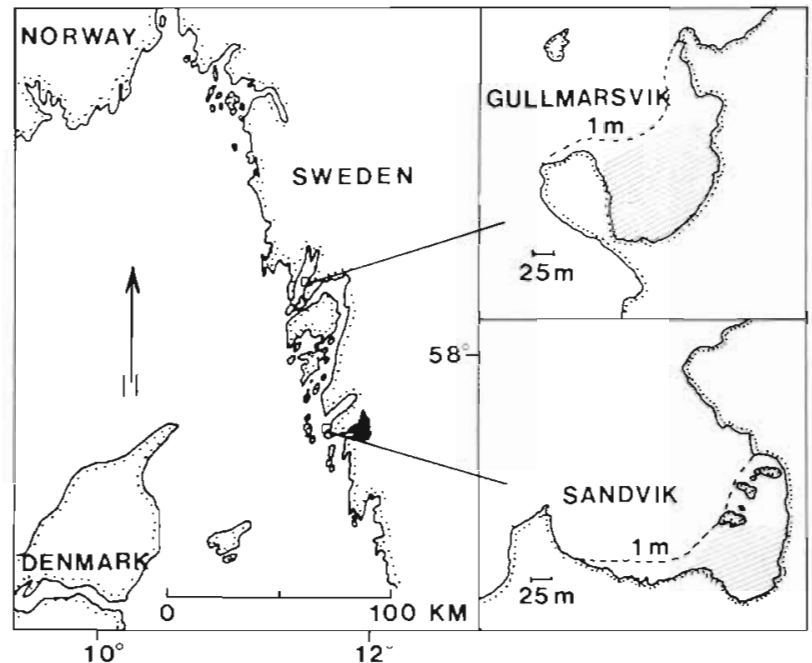

Fig. 1. Map of the areas studied: Gullmarsvik and Sandvik. lndicated are the depth line of $1 \mathrm{~m}$ (broken line) and the areas sampled (dashed areas)

$24 \%$, with extremes between 0 and $30 \%$, especially in autumn. A detailed description of temperature and salinity variability was given by Pihl \& Rosenberg (1982). Tidal amplitude at the localities is $0.1 \mathrm{~m}$, but high atmospheric pressure, especially in autumn, can occasionally reduce the mean sea level sufficiently to drain the areas.

Gullmarsvik faces north and is protected from the predominantly south-westerly winds. The area investigated covered $15000 \mathrm{~m}^{2}$ of sandy-silt sediment having $22 \%$ sand $(0.2$ to $2.0 \mathrm{~mm}), 72 \%$ silt $(0.002$ to $0.2 \mathrm{~mm})$ and $5 \%$ clay $(<0.002 \mathrm{~mm})$, based on weight. The content of organic matter in the sediment was between 0.7 and $2.4 \%$. Sandvik faces west and is partly sheltered by some islands. The area investigated covered $10000 \mathrm{~m}^{2}$ of sandy-silt sediments having $25 \%$ sand, $71 \%$ silt, $3 \%$ clay and an organic content between 0.6 and $1.6 \%$

\section{MATERIALS AND METHODS}

The mobile epifauna was sampled quantitatively at random with a drop-trap (Pihl \& Rosenberg 1982) 2 to 5 times $\mathrm{mo}^{-1}$ during daytime, from July to December in 1977 and from April to December in 1978. Night sampling in 3 different seasons gave food-selection values similar to those obtained at daytime sampling. The animals were preserved in $70 \%$ alcohol, and in the laboratory all animals were measured and separated into size classes. Maximum carapace widths of Carcinus maenas were measured under a stereo-microscope $(12 \times)$ and grouped into classes of $0.83,1.66$, 2.49 ...mm. For Pomatoschistus microps, $P$. minutus and Pleuronectes platessa total length was measured; size classes were $1 \mathrm{~mm}$ appart.

From each sample, 20 to 30 individuals of each species with stomach contents were selected randomly from the 0-group ( $<1 \mathrm{yr}$ ) and, if present, also from the 1-group. Identifiable prey specimens were counted and measured under a stereomicroscope to the nearest $0.1 \mathrm{~mm}$. In Carcinus maenas unidentifiable organic matter of animal and plant origin made up a considerable part of the food taken and is pooled here under the general heading 'detritus'. The organic material in the stomachs had a structure similar to the organic material partly covering the sediment surface in Gullmarsvik and could thus have resulted from direct ingestion, but could also be the result of masticated or partly digested animals and plants eaten by the crabs. In the fish species 'detritus' was of little importance in the diet. Dry weights of the dominant food species were obtained from measurements of average weight (zooplankton and meiofauna) or from length-weight relationships (macrofauna) (Tab. 1). Weights of Nereis spp. and 'detritus', however, were determined on what was found in the stomachs.

In Gullmarsvik in 1978, meiofauna was sampled in June and July with a $15 \mathrm{~cm}^{2}$ core down to $5 \mathrm{~cm}$ in the sediment. On each occasion 5 samples were taken and sieved on $0.2 \mathrm{~mm}$ sieves.

Samples for analysis of grain size and organic carbon were taken with a $15 \mathrm{~cm}^{2}$ plastic core down to $5 \mathrm{~cm}$ depth in the sediment at 4 to 18 randomly chosen sites every second month. Grain size was determined after sieving in 9 different sieves $(0.074$ to $64 \mathrm{~mm})$ and by sedimentation $(0.002$ to $0.074 \mathrm{~mm})$. Organic content was determined after drying at $60^{\circ} \mathrm{C}$ and ignition for $5 \mathrm{~h}$ at $550^{\circ} \mathrm{C}$.

$\mathrm{P} / \overline{\mathrm{B}}$ - and $\mathrm{P} / \mathrm{C}$-ratios were calculated from annual (Apr-Nov) production (P) mean annual biomass $(\bar{B})$ and annual consumption (C).

Food-niche overlap was calculated according to the equation:

$$
\mathrm{C}_{\mathrm{xy}}=\sum \min \mathrm{P}_{\mathrm{x} 1}, \mathrm{P}_{\mathrm{yi}}
$$

given by Hurlbert (1978), where $P_{x_{1}}=$ relative frequency (in weight) of food category i in the stomach of species $\mathrm{x}_{;} \mathrm{P}_{\mathrm{yt}}=$ corresponding frequency in species $\mathrm{y}$.

\section{RESULTS}

\section{Pomatoschistus microps (0-group)}

In 1977 the amphipod Corophium volutator was the dominant food organism, contributing up to $65 \%$ (by weight) of the food taken by juvenile Pomatoschistus microps in Gullmarsvik and up to $41 \%$ in Sandvik. In 
Table 1. Mean individual dry weight of dominant zooplankton, meio- and macrofauna eaten by the mobile epifauna. (A) Mean dry weight $(\mu \mathrm{g})$ per individual in zooplankton and meiofauna groups. (B) Relation between dry weight (W, mg) and length $(\mathrm{L}, \mathrm{mm})(\ln \mathrm{W}=\ln \mathrm{a}+\mathrm{b} \ln \mathrm{L})$ in macrofaunal species

\begin{tabular}{|c|c|c|c|c|c|c|}
\hline \multirow[t]{8}{*}{ (A) } & \multicolumn{2}{|l|}{ ZOOPLANKTON and MEIOFAUNA } & \multicolumn{2}{|c|}{ Weight $(\mu g)$} & \multicolumn{2}{|r|}{ Source } \\
\hline & Ostracoda & & & 15 & & B. Widbom (1984) \\
\hline & Harpacticoida & & & 1.7 & & B. Widbom (1984) \\
\hline & Calanoida & & & 2 & & U. Båmstet (pers. com.) \\
\hline & & & $1 \mathrm{~mm}$ & 0.1 & & \\
\hline & Nematoda & & $1-2 \mathrm{~mm}$ & 0.3 & & Stripp (1969) \\
\hline & & & $2 \mathrm{~mm}$ & 1.1 & & \\
\hline & Foraminifera & & & 1.5 & & Óhlund et al. (1975) \\
\hline (B) & MACROFAUNA & a & $\mathrm{b}$ & r & $\mathrm{n}$ & \\
\hline & Cardium edule & 0.094 & 3.09 & 0.99 & 40 & Möller \& Rosenberg (1983) \\
\hline & Mytilus edulis & 0.113 & 2.78 & 0.99 & 32 & Loo \& Rosenberg (1983) \\
\hline & Mya arenaria & 0.069 & 2.65 & 0.99 & 42 & Möller \& Rosenberg (1983) \\
\hline & Corophium volutator & 0.006 & 2.70 & 0.99 & 110 & Möller \& Rosenberg (1982) \\
\hline$\cdot$ & Crangon crangon & 0.420 & 2.85 & 0.99 & 80 & Pihl \& Rosenberg (1982) \\
\hline$\cdots$ & Carcinus maenas & 0.165 & 2.47 & 0.98 & 50 & Pihl \& Rosenberg (1982) \\
\hline$\cdot$ & Min. carapace length used & & & & & \\
\hline$\cdots$ & Max. carapace width used & & & & & \\
\hline
\end{tabular}

the latter area the polychaetes Nereis spp. were almost equally important and made up $38 \%$ of the food (Fig. 2). C. volutator and Nereis spp. were preferred by all sizes of fish but the smallest also ate meiofauna

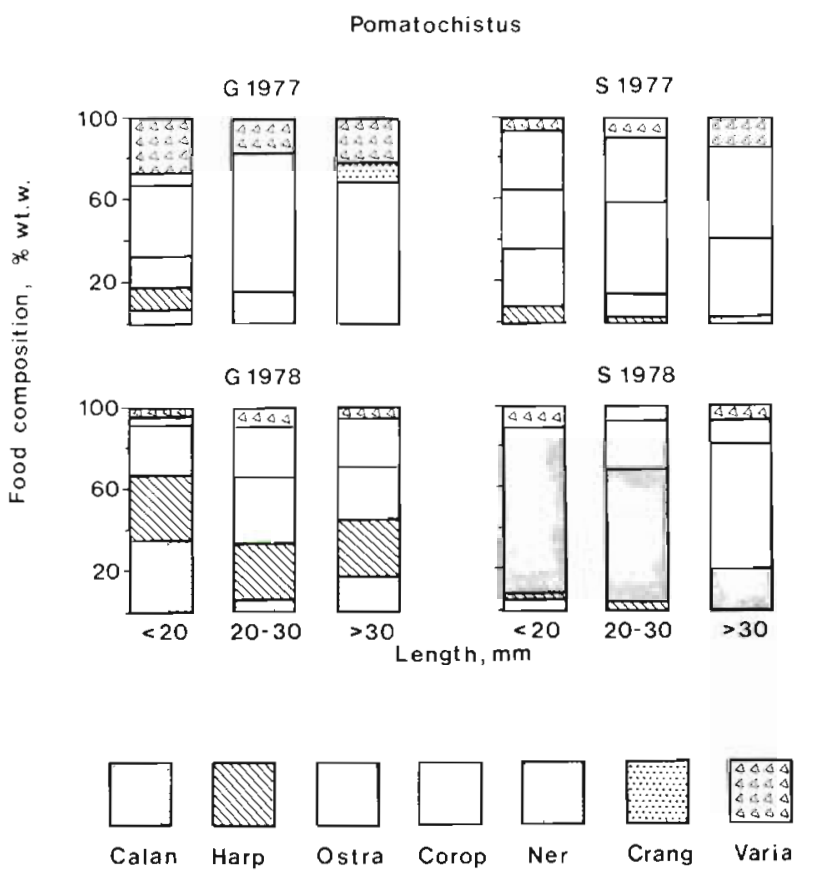

Fig. 2. Pomatoschistus microps. Food composition expressed as weight percentages in relation to fish size in Gullmarsvik (G) and Sandvik (S) in 1977-1978. Calanoids (Calan), harpacticoids (Harp), ostracods (Ostra), Corophium volutator (Corop), Nereis spp (Ner), Crangon crangon (Crang) and various (Varia) (mainly ostracods and harpacticoids) and calanoid copepods. In 1978, meiofauna and calanoid copepods were the most important food sources; together they contributed 72 and $64 \%$ of the food taken, based on weight in Gullmarsvik and Sandvik, respectively. Harpacticoid and calanoid copepods dominated in Gullmarsvik, whereas ostracods were mainly eaten in Sandvik. C. volutator was the most important benthic macrofauna species eaten in that year.

The feeding pattern changed during the season from eating meiofauna and small macrofauna species in summer, to mainly macrofauna in autumn. This was probably due to changes in the sizes of the predators, since Pomatoschistus microps grow from a size of 10 to $20 \mathrm{~mm}$, on their first appearence in the shallow areas in July, to a length of 30 to $40 \mathrm{~mm}$ at the time of leaving the areas in November. Other species or groups eaten by $P$. microps in the 2 areas were nematodes, oligochaetes, chironomids, Crangon crangon, Carcinus maenas, amphipods, molluscs and cladocerans. Adults (1-group) of $P$. microps were present in low densities in Sandvik during spring 1978. Their food consisted, in equal parts, of $C$. volutator and Nereis spp. which together contributed $95 \%$ of the food by weight.

\section{Pomatoschistus minutus (0-group)}

Juveniles of Pomatoschistus minutus were caught during summer and autumn 1978 in Gullmarsvik. Meiofauna (mainly harpacticoids) and calanoid 
copepods made up $17 \%$ of the diet and Corophium volutator, Crangon crangon and Carcinus maenas 55, 11 and $8 \%$ of the food by weight, respectively. Seasonal and size-dependent variations in the feeding pattern were small.

\section{Pleuronectes platessa (0-group)}

Juvenile Pleuronectes platessa were present only in Gullmarsvik. An analysis of their diet in 1977 was given by Mattson (1979); it was similar to the data for 1978 presented here. Harpacticoids were the dominant food for small $(<20 \mathrm{~mm}$ ) individuals in spring (AprMay) (Fig. 3). Later stages also ate ostracods, spionid polychaetes and Corophium volutator. $C$. volutator and the bivalves Mya arenaria, Cardium edule and Spisula subtruncata were the main food for larger $P$. platessa during summer. Other organisms taken were

\section{Carcinus}

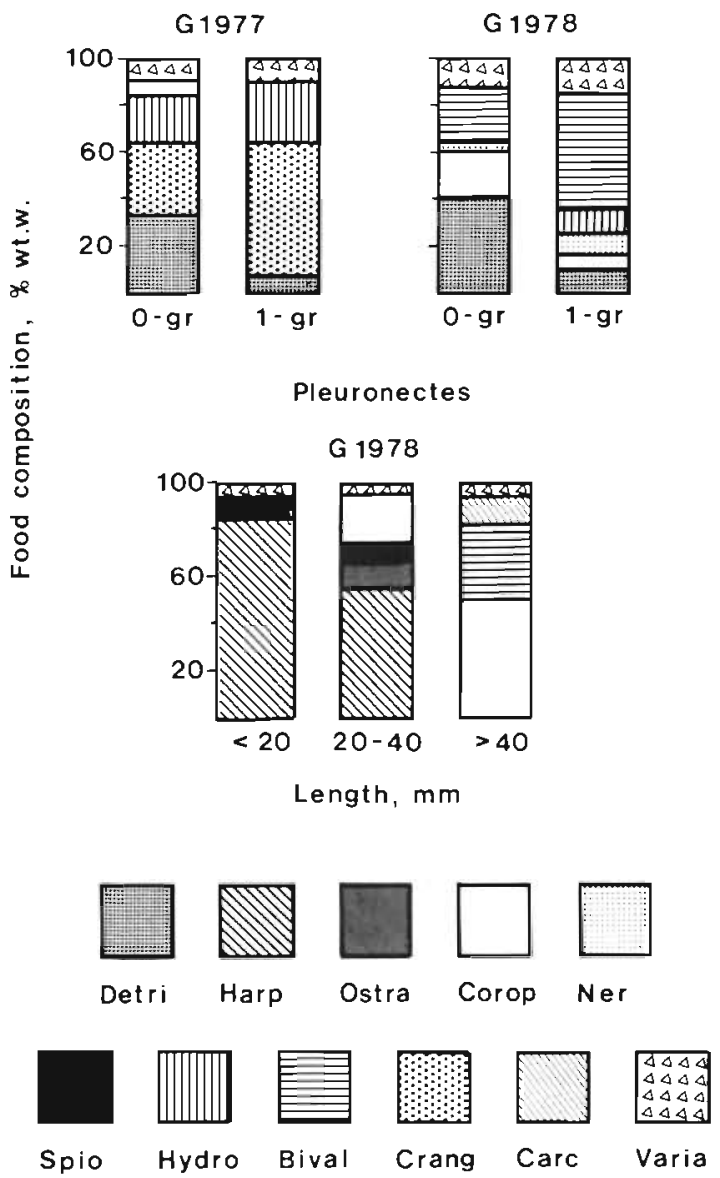

Fig. 3. Carcinus maenas and Pleuronectes platessa. Food composition expressed as weight percentages in relation to crab age and fish size in Gullmarsvik (G) in 1977-1978. Detritus (Detri), Spionidae (Spio), Hydrobia spp. (Hydro), bivalves (Bival), Carcinus maenas (Carc) and see also Fig. 2 nematodes, oligochaetes, polychaetes, Carcinus, Crangon and Hydrobia spp.

\section{Carcinus maenas (0- and 1-group)}

Carcinus maenas were only sampled in Gullmarsvik. Food selection was similar within the year classes which are therefore treated as a unit, without further separation according to size. Between 10 and $40 \%$ of the food eaten by 0 -group and 1 -group crabs could not be identified to species and is here listed as 'detritus' (Fig. 3). Food selection of both 0 - and 1-group was similar. In 1977 Crangon crangon and Hydrobia spp. were the dominant food items, whereas in 1978 Corophium volutator and the bivalves Mya arenaria, Cardium edule and Mytilus edulis were the most important. Other species eaten, but of minor importance, were harpacticoids, nematods, foraminiferans, Nereis spp. and oligochaetes.

\section{DISCUSSION}

\section{Food selection}

In the investigated areas on the Swedish west coast Pomatoschistus microps ate mainly small crustaceans (copepods and ostracods) and the amphipod Corophium volutator. In one area the polychaetes Nereis spp. were also taken. Investigations from eastern Denmark, the Federal Republic of Germany (Baltic and North Sea coasts) and east Scotland showed that gammarids, isopods, copepods, polychaetes and oligochaetes were the preferred food of $P$. microps (Healey 1972, Zander 1979, Schmidt-Moser \& Westphal 1981, Zander \& Hartwig 1982, Andersen 1983). In all areas small crustaceans were the dominant food item. Grazing on harpacticoid populations was reported by Schmidt-Moser \& Westphal (1981) and by Zander \& Hartwig (1982).

Corophium volutator was the main food item throughout the year for Pomatoschistus minutus in the Gullmarsvik in 1978, as was also found in an estuary in east Scotland by Healey (1971). The 0-group $P$. minutus are about $10 \mathrm{~mm}$ longer than $P$. microps when recruited to shallow areas of Gullmarsvik and this may explain why meiofauna was of lesser importance for $P$. minutus.

In 1977, 0-group Pleuronectes platessa in Gullmarsvik preferred Corophium volutator and Nereis spp. (Mattson 1979), whereas in 1978 they ate mainly harpacticoids, C. volutator and bivalves. Investigations from intertidal areas in the Wadden Sea and Great Britain showed that siphons from molluscs and tenta- 
cles and tails from polychaetes were the dominant food components for 0-group P. platessa (Edwards \& Steele 1968, Braber \& De Groot 1973, Kuipers 1977, De Vlas 1979, Lockwood 1980\}. In spring, young stages also ate copepods, juvenile crustaceans and small polychaetes (Macer 1967, Edwards \& Steele 1968, Thijssen et al. 1974, Lockwood 1980). On the east coast of Denmark, Bregnballe (1961) found that oligochaetes and copepods were the dominant food components of 0 group $P$. platessa. On the Swedish west coast, Evans (1983) found 0-group plaice mainly to feed harpacticoids, spionid polychaetes and bivalves. Hence, siphons from molluscs were of little importance in these 2 investigations, in agreement with this study. The reasons why siphons are of less importance as food in the Gullmarsvik is that shallow areas on the Swedish west coast are usually covered with ice for 2 to $3 \mathrm{mo}$ every winter, and that the adult population of bivalves are killed in most winters (Möller \& Rosenberg 1983). The absence of adults allows a high recruitment of many species utilized as food by $P$. platessa. The newly recruited small animals are probably preferred to cropping parts of the polychaetes.

'Detritus' (unidentifiable organic material), Crangon crangon, Hydrobia spp. and bivalves were the dominant food items taken by 0- and 1-group Carcinus maenas. In 1977 a low recruitment of bivalves was reported by Möller \& Rosenberg (1983); this could have been the reason why $C$. crangon and Hydrobia spp. became the dominant food that year. Small stages of $C$. crangon were also eaten by larger C. crangon in 1977 (Pihl \& Rosenberg 1984). 'Detritus' was mainly eaten by 0 -group C. maenas; it made up about $40 \%$ of the food taken. Ropes (1968) considered that C. maenas on the New England coast (USA) was omnivorous, as $50 \%$ of the crabs of $<30 \mathrm{~mm}$ carapace width fed on plant material, mainly Spartina. Animal food found included small molluscs (mainly Mytilus sp.) and small crustaceans in 40 and $30 \%$ of the crabs, respectively. For the Swedish west coast Eriksson \& Edlund (1977) suggested that 0-group C. maenas were micro-carnivores, extracting detritus and meiofauna from the sediment. Cage experiments in intertidal areas in the Wadden Sea revealed to Scherer \& Reise (1981) that $C$. maenas search for food by ploughing the sediment. 0 group individuals often rework systematically the upper $5 \mathrm{~mm}$ of the sediment and take nematodes, turbellarians, ostracods and juvenile macrofauna ( $\mathrm{Hy}$ drobia sp. and polychaetes). Scherer \& Reise calculated the number of animals removed from the sediment by enclosed $C$. maenas. They did not obtain information regarding the importance of detritus and plant material as potential food for $C$. maenas.

\section{Food consumption}

Food consumption of Crangon crangon was estimated by Pihl \& Rosenberg (1984). From evacuation rate and diel food intake the daily food consumption, expressed as percent of body weight, was calculated. Pihl \& Rosenberg showed that the annual food intake could be estimated by multiplying the daily mean biomass of the shrimp population over approximately $2 \mathrm{wk}$ periods by the daily food intake $(12.1 \%$ of shrimp weight).

In the present investigation daily food consumption was not determined, but appropriate values were taken from the literature (Table 2) and used to estimate the annual food consumtion of Pomatoschistus microps, P. minutus, Pleuronectes platessa and Carcinus maenas, in the same way as for $C$. crangon. The relevance of using daily food-intake values calculated at mean water temperature, instead of using values changing with temperature during the season, was demonstrated for the region investigated by Pihl \& Rosenberg (1984).

From July to November, when 0-group Pomatoschistus microps were present in Gullmarsvik and Sandvik, the mean water temperature was about $15^{\circ} \mathrm{C}$ and the value for food consumption, $8.6 \%$ of the body weight per day given by Andersen (1983), was used (Table 2). This value was also used for the closely related species $P$. minutus. The mean water temperature during the period (April-October), when 0-group Pleuronectes platessa were present in Gullmarsvik, was $13^{\circ} \mathrm{C}$ and the value for diel consumption, $9.9 \%$ of the body weight, given by Lochwood (1980), should be applicable here. For juvenile ( 1 to $100 \mathrm{mg}$ AFDW) Carcinus maenas mean daily food consumption was estimated at $20^{\circ} \mathrm{C}$ to be $28 \%$ of the body weight (Klein Breteler 1975). Wallace (1973) showed that the food intake of

Table 2. Mean daily food consumption as percent of body weight for 3 mobile epibenthic species

\begin{tabular}{|c|c|c|c|c|}
\hline Species & Area & $\begin{array}{l}\text { Temperature } \\
\left({ }^{\circ} \mathrm{C}\right)\end{array}$ & $\begin{array}{l}\text { Food consumption } \\
\text { ( } \% \text { of body weight) }\end{array}$ & Source \\
\hline Pomatoschistus microps (0-gr) & Nivå Bay, Denmark & 17 & 8.6 & Andersen (1983) \\
\hline Pleuronectes platessa $(0-\mathrm{gr})$ & Filey Bay, England & $11.5-12.7$ & 9.9 & Lockwood (1980) \\
\hline Carcinus maenas (0-gr) & Balgzand, Netherland & 20 & 28 & Klein Breteler (1975) \\
\hline
\end{tabular}


juvenile $C$. maenas at $24^{\circ} \mathrm{C}$ was 2.4 times higher than at $10^{\circ} \mathrm{C}$. Considering a linear change in food intake with temperature within the range 10 to $24^{\circ} \mathrm{C}$, the intake at $13^{\circ} \mathrm{C}$ (mean water temperature while $\mathrm{C}$. maenas was present in the area studied) should be $20 \%$ of the body weight per day.

The annual food consumption and food conversion of the four mobile epibenthic species in Gullmarsvik and Sandvik in 1977 and 1978 are summarized in Table 3, the calculations. This probably lead to an underestimate of food conversion in that year. The higher value (0.33) is therefore probably more correct. The lower consumption of $C$. maenas in the Wadden Sea, compared to this study, is mainly due to the lower biomass (Klein Breteler 1975). Scherer \& Reise (1981) calculated data from cage experiments; this could have caused underestimation of intake rates (see 'Food selection').

Table 3. Annual production (P), P/B-ratio, food consumption (C) and food conversion (P/C) of 4 mobile epibenthic species in Gullmarsvik (G) and Sandvik (S) in 1977 and 1978, compared to food consumption and food conversion in some other areas. Production and biomass data from Pihl \& Rosenberg (1982). All figures given as g AFDW $\mathrm{m}^{-2}$

\begin{tabular}{|c|c|c|c|c|c|c|c|}
\hline Species & & Area & $\mathrm{P}$ & $\mathrm{P} / \mathrm{B}$ & $\mathrm{C}$ & $\mathrm{P} / \mathrm{C}$ & Source \\
\hline Pomatoschistus microps & $(0-g r)$ & $\begin{array}{l}G(1977) \\
G(1978) \\
S(1977) \\
S(1978) \\
\text { Nivă Bay, Denmark }\end{array}$ & $\begin{array}{l}0.56 \\
0.42 \\
0.27 \\
0.43\end{array}$ & $\begin{array}{l}4.1 \\
3.0 \\
2.8 \\
4.2\end{array}$ & $\begin{array}{l}1.8 \\
1.6 \\
1.3 \\
1.3 \\
2.0\end{array}$ & $\begin{array}{c}0.31 \\
0.26 \\
0.21 \\
0.33 \\
0.26,0.47\end{array}$ & $\begin{array}{l}\text { This study } \\
\text { ". } \\
\text { "' } \\
\text { Andersen (1983) }\end{array}$ \\
\hline Pomatoschistus minutus & $(0-g r)$ & $\begin{array}{ll}G(1978) & \\
\text { Gullmar Fjord, } & (1976) \\
\text { Sweden } & (1977)\end{array}$ & 0.24 & 2.9 & $\begin{array}{l}1.0 \\
0.4^{\circ} \\
0.4^{\circ}\end{array}$ & $\begin{array}{l}0.25 \\
0.24 \\
0.45\end{array}$ & $\begin{array}{l}\text { This study } \\
\text { Evans (1983) } \\
\text { ". }\end{array}$ \\
\hline Pleuronectes platessa & $\begin{array}{l}(0-g r) \\
(0-g r) \\
(0-g r) \\
(0-g r) \\
(0-g r) \\
(0-g r) \\
(0-g r)\end{array}$ & $\begin{array}{l}\text { G (1977) } \\
\text { G (1978) } \\
\text { Balgzand, Netherland } \\
\text { Gullmar Fjord, (1976) } \\
\text { Sweden (1977) } \\
\text { Kyssing Fjord, Denmark } \\
\text { Loch Ewe, Scotland } \\
\text { Port Erin Bay, England } \\
\text { Balgzand, Netherland }\end{array}$ & $\begin{array}{l}0.24 \\
0.29\end{array}$ & $\begin{array}{l}1.8 \\
5.3\end{array}$ & $\begin{array}{c}1.0 \\
0.9 \\
0.03-0.3 \\
0.8^{\circ} \\
1.4^{\circ}\end{array}$ & $\begin{array}{c}0.20 \\
0.36 \\
0.20 \\
0.30-0.35\end{array}$ & $\begin{array}{l}\text { This study } \\
\quad \text { "' } \\
\text { Kuipers (1977) } \\
\text { Evans (1983) } \\
\quad \text { "' } \\
\text { Bregnballe (1961) } \\
\text { Edwards et al. (1969) } \\
\text { Colman (1970) } \\
\text { de Vlas (1979) }\end{array}$ \\
\hline Carcinus maenas & $\begin{array}{l}(0-\mathrm{gr}) \\
(1-\mathrm{gr}) \\
(0-\mathrm{gr}) \\
(1-\mathrm{gr}) \\
(0-\mathrm{gr}) \\
\text { (adult) }\end{array}$ & $\begin{array}{l}\text { G (1978) } \\
\text { G (1978) } \\
\text { Balgzand, Netherland } \\
\text { Island of Sylt, } \\
\text { F.R. Germany }\end{array}$ & $\begin{array}{l}0.94 \\
0.88\end{array}$ & $\begin{array}{l}6.5 \\
6.9\end{array}$ & $\begin{array}{l}4.3 \\
5.7 \\
0.8 \\
0.7 \\
3.6 \\
1.3\end{array}$ & $\begin{array}{l}0.22 \\
0.16 \\
0.30 \\
0.20\end{array}$ & $\begin{array}{l}\text { This study } \\
\text { Klein Breteler (1976) } \\
\text { ". } \\
\text { Scherer \& Reise } \\
\text { (1981) } \\
\text {." }\end{array}$ \\
\hline
\end{tabular}

together with comparative data from other areas. Food consumption and food conversion of Pomatoschistus microps in this study were in agreement with investigations in Nivå Bay, Denmark (Andersen 1983). The lower consumption values for $P$. minutus in the Gullmar Fjord and for $P$. platessa in the Wadden Sea, compared to this study, were due to lower population densities of the 2 species in those areas. In Gullmarsvik, food conversion $(\mathrm{P} / \mathrm{C})$ of 0 -group Pleuronectes platessa was estimated to be 0.23 and 0.33 in 1977 and 1978, respectively. In 1977, sampling started in July. Juvenile $P$. platessa are usually recruited to the area in April, thus the youngest stages were not included in
Following Crangon crangon, the 4 species investigated are the dominant representatives of the mobile epifauna in the shallow areas studied. Other epifaunal carnivores were found only occasionally, and large visiting fish had comparatively little importance in the infauna populations (Pihl 1982). Food consumption data for C. crangon were reported by Pihl \& Rosenberg (1984). In the Gullmarsvik in 1978, the total annual food consumption of Pomatoschistus microps, $P$. minutus, Pleuronectes platessa, Carcinus maenas and C. crangon $(12.4 \mathrm{~g})$ was estimated to be about $26 \mathrm{~g}$ AFDW $\mathrm{m}^{-2}$. In an adjacent bay in the Gullmar Fjord, Evans (1984) estimated the total annual consumption 
of the same epibenthic species in 1976 and 1977 to be 8.8 and $11.3 \mathrm{~g}$ dry weight (corresponding to 6.9 and $8.8 \mathrm{~g} \mathrm{AFDW}) \mathrm{m}^{-2}$, respectively. On a tidal flat in the Dutch Wadden Sea the total annual consumption of mobile epifauna (Crangon, Carcinus, Pleuronectes, Platichthys, Pomatoschistus) was estimated to be $6.3 \mathrm{~g}$ $\mathrm{C} \mathrm{m}^{-2}$ corresponding to $15.6 \mathrm{~g}$ AFDW (Kuipers \& Dapper 1981, Kuipers et al. 1981). The lower food consumption in these investigations, compared to this study, is mainly due to the use of higher food-conversion factors (e.g. for C. crangon) and to the lower densities of some of the mobile epifauna species in these areas. In addition, in the former study the production value used for $C$. maenas was probably to low.

The food conversion factor for Crangon crangon was

\section{Food consumption in relation to prey species}

The total annual consumption of the 4 species investigated, separated into dominant food components, are shown for Gullmarsvik in 1978 in Table 4. Proportional allocation of different prey species was estimated from data on mean food percentage composition for each species in the stomachs during approximately $2 \mathrm{wk}$ periods, multiplied by total food intake during each period. Copepods and ostracods contributed $72 \%$, and Corophium volutator $21 \%$, of the food taken by the 0 group population of Pomatoschistus microps in Gullmarsvik in 1978 (Table 4). For 0-group $P$. minutus, $C$. volutator comprised $66 \%$, meiofauna $15 \%$ of the food taken.

Table 4. Annual food consumption by Pomatoschistus microps, Pomatoschistus minutus, Pleuronectes platessa and Carcinus maenas of dominant meiofauna groups, macrofauna and epifauna species, and detritus in Gullmarsvik in 1978. All data given as mg AFDW $\mathrm{m}^{-2}$ (and as \% of total consumption)

\begin{tabular}{|c|c|c|c|c|c|c|c|c|c|c|}
\hline \multirow{2}{*}{$\begin{array}{l}\text { Food source } \\
\text { Calanoida }\end{array}$} & \multicolumn{2}{|c|}{$\begin{array}{c}P . \text { microps } \\
0-\mathrm{gr}\end{array}$} & \multicolumn{2}{|c|}{$\begin{array}{l}\text { P. minutus } \\
0-\mathrm{gr}\end{array}$} & \multicolumn{2}{|c|}{$\begin{array}{l}\text { P. platessa } \\
0-\mathrm{gr}\end{array}$} & \multicolumn{4}{|c|}{ C. maenas } \\
\hline & 279 & (19) & 45 & (4) & & & & & & \\
\hline \multicolumn{11}{|l|}{ MEIOFAUNA } \\
\hline Harpacticoida & 453 & $(28)$ & 44 & (4) & 91 & $(10)$ & 66 & (2) & & \\
\hline Ostracoda & 407 & $\{25\}$ & 105 & (11) & 19 & (2) & 20 & (1) & & \\
\hline \multicolumn{11}{|l|}{ MACROFAUNA } \\
\hline Corophium volutator & 337 & $(21)$ & 635 & $(66)$ & 404 & $(45)$ & 854 & $(20)$ & 341 & $(6)$ \\
\hline Nereis spp. & 10 & (1) & 27 & (3) & & & 171 & (4) & 227 & (4) \\
\hline Mya arenaria & 14 & (1) & 18 & (2) & 41 & (5) & 202 & (5) & 648 & (11) \\
\hline Cardium edule & & & & & 79 & (9) & 45 & (1) & 325 & (6) \\
\hline Spisula subtruncata & & & & & 20 & (2) & & & & \\
\hline Mytilus edulis & & & & & & & 735 & $(17)$ & 2210 & (39) \\
\hline Hydrobia spp. & & & & & & & & & 511 & (9) \\
\hline \multicolumn{11}{|l|}{ EPIFAUNA } \\
\hline Crangon crangon & 35 & (2) & & (8) & 24 & (3) & & & & \\
\hline Carcinus maenas & & & 10 & (1) & 125 & (14) & & & & \\
\hline Detritus & & & & & & & 1794 & $(42)$ & 568 & (10) \\
\hline Other & 47 & (3) & 10 & (1) & 89 & $(10)$ & 384 & (9) & 852 & (15) \\
\hline Total food consumption & 1603 & & 966 & & 892 & & 4271 & & 5683 & \\
\hline
\end{tabular}

0.19 (Pihl \& Rosenberg 1984). In this study, food conversion for 0 - and 1-group Carcinus maenas was calculated to be 0.22 and 0.16 , respectively. For 0 -group of Pomatoschistus microps and $P$. minutus it was calculated to be 0.26 to 0.33 , and for Pleuronectes platessa, to be 0.33 . These data suggest that for decapod crustaceans and small fish in shallow areas of western Sweden mean annual food conversions of about 0.20 and 0.30 , respectively, could be used for crude estimates. According to Brett \& Groves (1979), young carnivorous fish have food conversions between 0.23 and 0.45 .
Corophium volutator, bivalves and juvenile Carcinus maenas were the dominant food components taken by 0-group Pleuronectes platessa, together comprising $75 \%$ of the food consumed. Meiofauna, the main food for $P$. platessa $<40 \mathrm{~mm}$, contributed only $11 \%$ of the total food taken by 0 -group $P$. platessa.

Detritus, Corophium volutator and bivalves made up most of the food taken by 0 -group Carcinus maenas. In 1-group individuals, bivalves dominated, comprising $56 \%$ of the food taken.

In Gullmarsvik, during June and July, the abun- 
dances of harpacticoids and ostracods were estimated to be about 120000 and $15000 \mathrm{~m}^{-2}$, respectively. With a mean individual weight (AFDW) of harpacticoids and ostracods, sieved in $0.2 \mathrm{~mm}$ sieves, of 1.4 and $7.2 \mu \mathrm{g}$ (Widbom 1984) the mean biomass in the area was about 170 and $110 \mathrm{mg} \mathrm{AFDW} \mathrm{m}^{-2}$, respectively. These are minimum values because of the large (0.2 mm) sieves used. In an adjacent bay, Evans (1983) estimated, in June and November, the biomass of harpacticoids and ostracods to be 160 to 240 and 100 to $140 \mathrm{mg} \mathrm{dwt} \mathrm{m}^{-2}$, respectively. He suggested a $\mathrm{P} / \mathrm{B}$ ratio of about 10 for these meiofauna groups. Gerlach (1971) used a P/B ratio of 9 as a general figure for marine meiobenthos.

Using a $\mathrm{P} / \mathrm{B}$ ratio of 10 , the annual production of harpacticoids and ostracods in Gullmarsvik 1978 was roughly estimated to be 1.7 and $1.1 \mathrm{~g} \mathrm{AFDW} \mathrm{m}^{-2}$, respectively. Evans (1983) estimated an annual production of all meiofauna to be $5 \mathrm{~g} \mathrm{dwt} \mathrm{m}^{-2}$.

Annual production of the dominant prey species among macrofauna and mobile epifauna in Gullmarsvik in 1978 were given by Möller \& Rosenberg (1982, 1983), Möller (unpubl.) and Pihl \& Rosenberg (1982). In Table 5, the annual consumption of Ponatoschistus edule, and $14 \%$ of Nereis spp. Among the epifauna $113 \%$ of the production of C. maenas and $29 \%$ of $C$. crangon was consumed. C. maenas consumption presumably exceeds production in the area because it predates here mainly on the small postlarval and megalopa stages. These larval and postlarval forms are transported into the area intermittently throughout summer and early autumn, and settle in the shallow area, comprising an important food resource for the epibenthic fauna. Thus, this food resource is mainly produced outside the shallow area and is therefore underestimated in the epifauna production within the area.

Evans (1984) also reported a high predation pressure from the epifauna on some infauna and epifauna species. Of the annual production of crustaceans (mainly Corophium volutator and Crangon crangon) 67 and 60 to $80 \%$, respectively, were taken by the epifauna. Of the production of polychaetes Evans found that $4 \%$ was eaten.

The heavy predation on most of the dominant infaunal species indicates that the epifauna play a major role as regulators in this community. The impact of epifaunal carnivores on infauna has been examined

Table 5. Annual consumption by dominant mobile epifauna species, and annual production of some meiofauna groups and macrofauna and mobile epifauna species in Gullmarsvik 1978. All values given as $\mathrm{g} \mathrm{ADFW} \mathrm{m}^{-2} \mathrm{yr}^{-1}$. Consumption, expressed as $\%$ of production, given in parentheses. Production estimates from Möller \& Rosenberg (1982, 1983), Möller (in ms, for Nereis) and Pihl \& Rosenberg (1982). Consumption by Crangon crangon from Pihl \& Rosenberg (1984)

\begin{tabular}{|c|c|c|c|c|c|c|c|}
\hline Food source & Production & $\begin{array}{l}\text { Pomatoschi- } \\
\text { stus microps } \\
\quad(0-\mathrm{gr})\end{array}$ & $\begin{array}{c}\text { Pomatoschi- } \\
\text { stus minutus } \\
\quad(0-\mathrm{gr})\end{array}$ & $\begin{array}{l}\text { CONSUMPTIOI } \\
\text { Pleuronectes } \\
\text { platessa } \\
(0-\mathrm{gr})\end{array}$ & $\begin{array}{l}\text { Carcinus } \\
\text { maenas } \\
(0-1-\mathrm{gr})\end{array}$ & $\begin{array}{l}\text { Crangon } \\
\text { crangon } \\
(0-1-g r)\end{array}$ & Total \\
\hline \multicolumn{8}{|l|}{ MEIOFAUNA } \\
\hline Harpacticoida & 1.7 & $0.45(28)$ & $0.04 \quad(3)$ & $0.09(6)$ & $0.06(4)$ & $0.30(19)$ & $0.95(60)$ \\
\hline Ostracoda & 1.1 & $0.41 \quad(37)$ & 0.11 (9) & $0.02(2)$ & $0.02(2)$ & $0.53(48)$ & $1.08(98)$ \\
\hline \multicolumn{8}{|l|}{ MACROFAUNA } \\
\hline Corophium volutator & 6.3 & $0.34(5)$ & $0.64(10)$ & $0.40(7)$ & $1.20(19)$ & $3.60(57)$ & $6.17(98)$ \\
\hline Nereis spp. & 11.2 & $0.01(<1)$ & $0.03(<1)$ & & $0.40 \quad(4)$ & $1.10(10)$ & $1.54(14)$ \\
\hline Mya arenaria & 3.6 & $0.01(<1)$ & $0.02(<1)$ & 0.04 (1) & $0.85(24)$ & $1.30(36)$ & $2.22(62)$ \\
\hline Cardium edule & 1.9 & & & $0.08(4)$ & $0.37(20)$ & $1.30(68)$ & $1.75(92)$ \\
\hline \multicolumn{8}{|l|}{ MOBILE EPIFAUNA } \\
\hline Crangon crangon & 2.2 & $0.04(2)$ & $0.07 \quad(3)$ & $0.02(1)$ & & $0.50(23)$ & $0.63(29)$ \\
\hline Carcinus maenas & 1.8 & $0.01 i<1)$ & $0.01(<1)$ & $0.13(7)$ & & $1.90(105)$ & 2.04 (113) \\
\hline
\end{tabular}

microps, P. minutus, Pleuronectes platessa, Carcinus maenas (Table 3) and Crangon crangon (from Pihl \& Rosenberg 1984) are compared with the production of dominant food components among meiofauna, macrofauna and mobile epifauna in Gullmarsfjord in 1978. Among the infauna the mobile epifauna consumed 60 to $98 \%$ of the production of harpacticoids, ostracods, Corophium volutator, Mya arenaria and Cardium in a series of cage experiments from various geographic areas (e.g. Reise 1977, Virnstein 1977, Peterson 1979). These experiments revealed that - where either epifaunal or infaunal species were studied - the epifauna regulate the quantity of infauna; however, lack of such effects has also been suggested (Berge \& Hesthagen 1981).

In this study, interactions between epifauna and 
infauna were assessed from direct and simultaneous measurements of production of prey and consumption of predators in the natural habitat. This was also done by Evans (1984) and he found that 24 to $34 \%$ of the total production of infauna was eaten by the epifauna. Epifauna-infauna interrelations will be discussed further in a later paper dealing mainly with functional aspects of the shallow soft bottom ecosystem on the Swedish west coast.

\section{Food-niche overlap and food competition}

The 5 dominant epifaunal predators are, in this study, all considered to be opportunistic carnivores, mainly feeding on infauna which they select on the basis of relative availability. To investigate resource partitioning between these species, food-niche overlap was calculated each month from May to November in Gullmarsvik in 1978. Mean food-niche overlap between pairs of epibenthic species was estimated to be 0.27 (Table 6). The largest overlap was found between the 2 Pomatoschistus species and between Pleuronectes platessa and Crangon crangon; the smallest overlap, between Carcinus maenas and Pomatoschistus species. In an adjacent shallow bay, Evans (1983) also found a large overlap between $P$. platessa and C. crangon.

In general, the degree of overlap decreased with increasing difference in body size between 2 predator species, as small-sized animals mainly feed on meiofauna and larger ones on macrofauna. This is clearly shown by the overlap between Pleuronectes platessa, Crangon crangon and Carcinus maenas. In spring, recently settled 0-group $P$. platessa exhibited a small overlap with 1 -group $C$. crangon and $C$. maenas, whereas during summer when 0 -group $C$. crangon and
$C$. maenas were recruited to the area and $P$. platessa was larger, the degree of overlap increased. The increased overlap in summer could have, in part, been caused by the higher epifauna densities during this season.

Corophium volutator was eaten by all species in the mobile epifauna community, and contributed on average $58 \%$ of the food-niche overlap between pairs of predators. The high preference for $C$. volutator and the fact that the epifauna together consumed $98 \%$ (Table 5) of the annual production of C. volutator in 1978, implies that competition for this prey species occurs between predators. Fig. 4 compares the cumulative annual production of $C$. volutator in Gullmarsvik in 1978 to the cumulative consumption of the 5 epibenthic predators. In the same year, mobile epifaunal

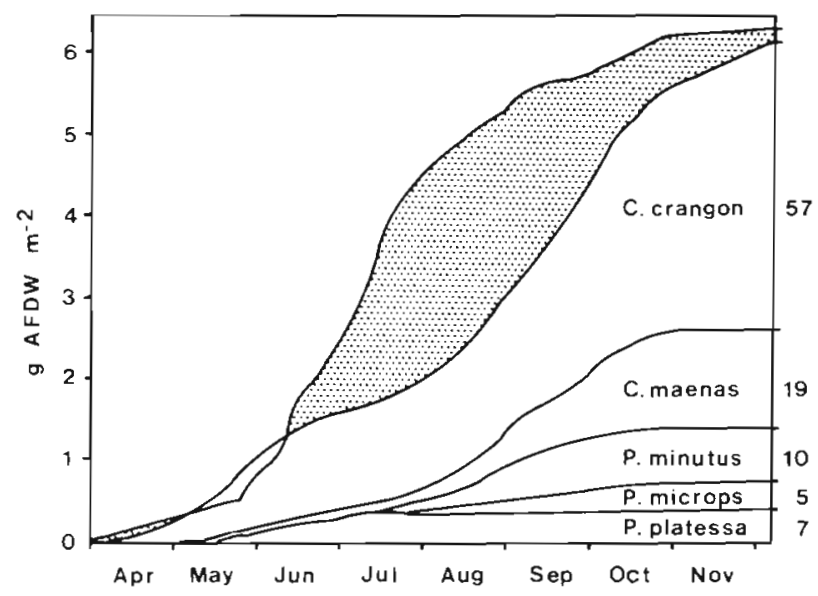

Fig. 4. Cumulative production of Corophium volutator and cumulative consumption by $C$. volutator of dominant mobile epifaunal predators. Consumption (in percentages) of $C$ volutator production by the predators given in right ordinate All figures in $\mathrm{g}$ AFDW $\mathrm{m}^{-2}$. (Production of $C$. volutator from Möller \& Rosenberg 1982)

Table 6. Food-niche overlap $\left(\mathrm{C}_{\mathrm{xy}}\right)$ between all pairs of species studied: Pomatoschistus microps, P. minutus, Pleuronectes platessa, Carcinus maenas and Crangon crangon in Gullmarsvik each month in 1978

\begin{tabular}{|c|c|c|c|c|c|c|c|c|c|}
\hline Species & Apr & May & Jun & Jul & Aug & Sep & Oct & Nov & Mean \\
\hline F. microps/F. minutus & - & - & - & 0.22 & 0.39 & 0.22 & 0.80 & 0.86 & 0.50 \\
\hline P. microps/P. platessa & - & - & - & 0.06 & 0.29 & 0.14 & 0.21 & - & 0.18 \\
\hline F. microps/C. maenas & - & - & - & 0.05 & 0.18 & 0.08 & 0.14 & 0.03 & 0.10 \\
\hline P. microps/C. crangon & - & - & - & 0.08 & 0.18 & 0.24 & 0.31 & 0.11 & 0.18 \\
\hline$F$ minutus/ $F$. platessa & - & - & - & 0.62 & 0.27 & 0.29 & 0.23 & - & 0.35 \\
\hline$P$. minutus $/ C$ maenas & - & - & - & 0.29 & 0.15 & 0.15 & 0.14 & 0.04 & 0.15 \\
\hline F. minutus/C. crangon & - & - & - & 0.29 & 0.18 & 0.35 & 0.35 & 0.10 & 0.25 \\
\hline P. platessa/C. maenas & 0 & 0.03 & 0.24 & 0.24 & 0.39 & 0.21 & 0.36 & - & 0.24 \\
\hline$F$. platessa/C. crangon & 0 & 0.03 & 0.68 & 0.40 & 0.67 & 0.49 & 0.39 & - & 0.44 \\
\hline C. maenas/C.crangon & 0.37 & 0.42 & 0.30 & 0.38 & 0.48 & 0.29 & 0.19 & 0.26 & 0.33 \\
\hline $\begin{array}{l}\text { Mean overlap for } \\
\text { mobile epifauna }\end{array}$ & 0.12 & 0.16 & 0.41 & 0.26 & 0.32 & 0.25 & 0.31 & 0.23 & \\
\hline
\end{tabular}


carnivores also consumed 92 and $62 \%$ of the annual production of 0-group Cardium edule and Mya arenaria, respectively (Table 5). These 2 bivalve species were mainly eaten during July and August by Crangon crangon, Carcinus maenas and Pleuronectes platessa, and competition between these predators seems to occur especially during this month. In 1978 , for example, $C$. edule contributed during July more than $29 \%$, and during August more than $46 \%$, of the food taken by both $C$. crangon and $P$. platessa, and made up about $70 \%$ of the food-niche overlap between the 2 predators during these months.

In an adjacent estuary, Thorman (1982) found an increase in food-niche overlap when the food supply was diminishing in mid summer in a guild of small fishes. He interpreted this as increasing competition for food during the season. In a laboratory study, competition for food was shown to exist between Pomatoschistus microps and $P$. minutus (Magnhagen \& Wiederholm 1982).

Pihl \& Rosenberg (1984) showed that recently settled Crangon crangon were an important food for adult $C$. crangon in Gullmarsvik and Sandvik, particularly in 1977. However, among the other 4 dominant epifaunal species in the areas studied here, cannibalism was rare or absent. Ropes (1968) suggests that cannibalism is unusual in Carcinus maenas because juveniles and adults are living in different habitats. This is also the case on the Swedish west coast where the 0-group $C$. maenas mainly occur in the shallowest $(0$ to $0.7 \mathrm{~m})$ part on the shore, whereas adults prefer Zostera marina or Fucus spp. beds and deeper water (Pihl \& Rosenberg 1982, Baden \& Pihl 1984). Juveniles of the fish species studied in the area also live mainly separated from the adult population, and this may explain the absence of cannibalism.

Acknowledgements. I sincerely thank my colleagues Mrs. S. P. Baden, Mr. P. Möller, Dr. T. Pearson and Dr. R. Rosenberg for their critical review of this paper. Dr. T. Pearson also improved the style of the manuscript. Financial support was given by the Swedish Environmental Protection Board.

\section{LITERATURE CITED}

Andersen, N. G. (1983). Lerkutlingen Pomatoschistus microps (Kr.) i Nivå bugt. Final thesis from University of Copenhagen

Baden, S. P., Pihl, L. (1984). Abundance, biomass and production of mobile epibenthic fauna in Zostera marina (L.) meadows, western Sweden. Ophelia 23 (1): 65-90

Berge, J. A., Hesthagen, I. H. (1981). Effects of epibenthic macropredators on community structure in an eutrophicated shallow water area, with special reference to food consumption by the common goby Pomatoschistus microps. Kieler Meeresforsch. Sonderh. 5: 462-470

Braber, L., De Groot, S. J. (1973). The food of five flatfish species (Pleuronectiformes) in the southern North Sea. Neth. J. Sea Res. 6 (1-2): 163-172

Bregnballe, F. (1961). Plaice and flounder as consumers of the microscopic bottom fauna. Meddr Danm. Fisk.-og. Havunders, N.S. $3(6)$ : $133-182$

Brett, J. R., Groves, T. D. D. (1979). Physiological energetics. In: Hoar, W. S., Randall, D. J., Brett, J. R. (ed.) Fish physiology, Vol. VIII, Chapter 6. Academic Press, New York and London, p. 279-352

Colman, J. A. (1970). On the efficiency of food conversion of young plaice (Pleuronectes platessa). J. mar. biol. Ass. U.K. 50: 113-120

De Vlas, J. (1979). Annual food intake by plaice and flounder in the tidal flat area in the Dutch Wadden Sea, with special reference to consumption of regenerating parts of macrobenthic prey. Neth. J. Sea Res. 13: 117-153

Edwards, R., Steele, J. H. (1968). The ecology of 0-group plaice and common dabs at Loch Ewe. I. Population and food. J. exp. mar. Biol. Ecol. 2: 215-238

Edwards, R., Finlayson, D. M., Steele, J. H. (1969). The ecology of 0 -group plaice and common dabs at Loch Ewe. II. Experimental studies of metabolism. J. exp. mar. Biol. Ecol. 3: 1-17

Eriksson, S., Edlund, A.-M. (1977). On the ecological energetics of 0-group Carcinus maenas (L.) from a shallow sandy bottom in Gullmar fjord, Sweden. J. exp. mar. Biol. Ecol. 30: $233-248$

Evans, S. (1983). Production, predation and food niche segregation in a marine shallow soft-bottom community. Mar Ecol. Prog. Ser. 10: 147-157

Evans, S. (1984), Energy budgets and predation impact of dominant epibenthic carnivores on a shallow soft bottom community at the Swedish west coast. Estuar. coast. Shelf Sci. 18: 651-672

Gerlach, S. A. (1971). On the importance of marine meiofauna for benthic communities. Oecologia (Berl.) 6: 176-190

Healey, M. C. (1971). The distribution and abundance of sand gobies, Gobius minutus, in the Ythan estuary. J. Zool., Lond. 163: 177-229

Healey, M. C. (1972). On the population ecology of the common goby in the Ythan estuary. J. nat. Hist. 6: 133-145

Hurlbert, S. A. (1978). The measurement of niche overlap and some relatives. Ecology 59: 67-77

Klein Breteler, W. C. M. (1975). Food consumption, growth and energy metabolism of juvenile shore crabs, Carcinus maenas. Neth. J. Sea Res. 9: 255-272

Klein Breteler, W. C. M. (1976). Settlement, growth and production of the shore crab, Carcinus maenas on tidal flats in the Dutch Wadden Sea. Neth. J. Sea Res. 10: 354-376

Kuipers, B. R. (1977). On the ecology of juvenile plaice on a tidal flat in the Wadden Sea. Neth. J. Sea Res. 11: 56-91

Kuipers, B. R., Dapper, R. (1981). Production of Crangon crangon in the tidal zone of the Dutch Wadden Sea. Neth. J. Sea Res. 15 (1): 33-53

Kuipers, B. R., De Wilde, P. A. W. J., Creutzberg, F. (1981). Energy flow in a tidal flat ecosystem. Mar. Ecol. Prog. Ser. 5: 215-221

Lockwood, S. J. (1980). The daily food intake of 0-group plaice (Pleuronectes platessa L.) under natural conditions. J. Cons. int. Explor. Mer 39: 154-159

Loo, L.-O., Rosenberg, R. (1983). Mytilus edulis culture: growth and production in western Sweden. Aquaculture 35: $137-150$

Macer, C. T. (1967). The food web in Red Wharfe Bay (North Wales) with particular reference to young plaice (Pleuronectes platessa). Helgoländer wiss. Meeresunters. 15: $560-573$ 
Magnhagen, C., Wiederholm, A.-M. (1982). Habitat and food preferences of Pomatoschistus minutus and P. microps (Gobiidae) when alone and together: an experimental study. Oikos 39: 152-156

Mattson, J. (1979). Populationsuppskattning och födoval av 0gruppens rödspättor (Pleuronectes platessa) och skrubbor (Platichthys flesus) i en grund vik i Gullmarsfjorden under juli-oktober 1977. Final thesis from University of Gothenburg

Möller, P., Rosenberg, R. (1982). Production and abundance of the amphipod Corophium volutator in some marine habitats on the west coast of Sweden. Neth. J. Sea Res. 16: $127-140$

Möller, P., Rosenberg, R. (1983). Recruitment, abundance and production of Mya arenaria and Cardium edule in marine shallow waters, western Sweden. Ophelia 22: 33-55

Ohlund, E., Olsson, I., Rosenberg, R., Thorell, L. (1975). The By Fjord: ecological investigations on zooplankton, benthic meio- and macrofauna and bacteria in the BY Fjord. Swedish Environmental Protection Board P.M. 568: $1-94$

Peterson, C. H. (1979). Predation, competitive exclusion and diversity in the soft sediment benthic community of estuaries and lagoons. Mar. Sci. 10: 233-264

Pihl, L. (1982). Food intake of young cod and flounder in a shallow bay on the Swedish west coast. Neth. J. Sea Res 15: 419-432

Pihl, L., Rosenberg, R. (1982). Production, abundance and biomass of mobile epibenthic marine fauna in shallow waters, western Sweden. J. exp. mar. Biol. Ecol. 57: 273-301

Pihl, L., Rosenberg, R. (1984). Food selection and consumption of the shrimp Crangon crangon in some shallow marine areas in western Sweden. Mar. Ecol. Prog. Ser. 15: 159-168

Reise, K. (1977). Predator exclusion experiments in an intertidal mud flat. Helgoländer wiss. Meeresunters. 30: 263-271
Ropes, J. W (1968). The feeding habit of the green crab Carcinus maenas (L.). Fish. Bull. U.S. 67: 183-203

Scherer, B., Reise, K. (1981). Significant predation on microand macrobenthos by the crab Carcinus maenas $\mathrm{L}$. in the Wadden Sea. Kieler Meeresforsch. Sonderh. 5: 490-500

Schmidt-Moser, R., Westphal, D. (1981). Predation of Pomatoschistus microps Kroyer and $P$. minutus Pallas (Gobiidae, Pisces) on macro- and meiofauna in the brackish fjord Schlei. Kieler Meeresforsch. Sonderh. 5: 471-478

Stripp, K. (1969), Jahreszeitliche Fluktuationen von Makrofauna und Mikrofauna in der Helgoländer Bucht. Veröf. Inst. Meeresforsch. Bremerh. 12: 65-94

Thijssen, R., Lever, A. J., Lever, J. (1974). Food composition and feeding periodicity of 0 -group plaice (Pleuronectes platessa) in the tidal area of a sandy beach. Neth. J. Sea Res. 8: 369-377

Thorman, S. (1982). Niche dynamics and resource partitioning in a fish guild inhabiting a shallow estuary on the Swedish west coast. Oikos 39: 32-39

Virnstein, R. W. (1977). The importance of predation by crabs and fishes on benthic infauna in Chesapeake Bay. Ecology 58: $1199-1217$

Wallace, J. C. (1973). Feeding, starvation and metabolic rate in the shore crab Carcinus maenas. Mar. Biol. 20: 277-281

Widbom, B. (1984). Determination of average individual dry weights and ash-free dry weights in different sieve fractions of marine meiofauna. Mar. Biol. 84: 101-108

Zander, C. D. (1979). On the biology and food of small-sized fish from the North and Baltic Sea areas. II. Investigation of a shallow stony ground off Men, Denmark. Ophelia 18: $179-190$

Zander, C. D., Hartwig, E. (1982). On the biology and food of small-sized fish from North and Baltic Sea areas. IV. Investigations on an euljttoral mud flat at Sylt Island. Helgoländer Meeresunters. 35: 47-63 